\title{
PERAN VITAL PENELUSURAN ASET GUNA MENENTUKAN BESARAN PIDANA TAMBAHAN UANG PENGGANTI TERHADAP KORUPTOR*
}

\author{
B.G.M. Widipradnyana Arjaya \\ Kejaksaan Negeri Sintang \\ Jl. Soeprapto No.2A Sintang \\ Email: arjaya@gmail.com \\ DOI: $10.15408 /$ jch.v4i1.2656
}

\begin{abstract}
The imposition of additional criminal restitution is one distinguishing feature of corruption with other criminal offenses. In practice points verdict compensation often at variance with the prosecution, because of the inability to prove liability for compensation to be paid. Moreover, when the execution court decision found the fact that the property owned by the convicted person is not sufficient for compensation. It is necessary for traceability measures assets resulting from corruption in the possession of criminals, so that the prosecution has a strong foundation, so that the judges who examine and decide the case can be assured as well as the execution of the judgment can be up to reimburse the state, without the reverse charge state with the imposition subsidiair prison active replacement.
\end{abstract}

Keywords: corruption, money substitutes, asset tracking

\begin{abstract}
Abstrak: Pengenaan pidana tambahan uang pengganti merupakan salah satu ciri pembeda tindak pidana korupsi dengan tindak pidana lainnya. Dalam praktiknya poin putusan uang pengganti sering kali berbeda dengan tuntutan jaksa, karena tidak dapat dibuktikannya kewajiban pembayaran uang pengganti yang harus dibayarkan. Selain itu, saat melakukan eksekusi putusan pengadilan ditemukan fakta bahwa harta yang dimiliki oleh terpidana tidak mencukupi pembayaran uang pengganti. Untuk itu diperlukan tindakan penelusuran aset hasil korupsi yang berada dalam penguasaan koruptor, agar tuntutan jaksa memiliki dasar yang kuat, sehingga hakim yang memeriksa dan memutus perkara dapat teryakini serta pelaksanaan eksekusi putusan dapat maksimal mengembalikan uang negara, tanpa sebaliknya membebankan negara dengan pengenaan subsidiair penjara pengganti yang aktif.
\end{abstract}

Kata Kunci: korupsi, uang pengganti, penelusuran aset

\footnotetext{
${ }^{*}$ Naskah diterima: 20 Maret 2016, direvisi: 23 April 2016, disetujui untuk terbit: 22 Mei
} 2016. 


\section{B.G.M. Widipradnyana Arjaya}

\section{Pendahuluan}

Korupsi telah menjadi kejahatan yang dianggap merusak sendi-sendi kehidupan bermasyarakat dan bernegara. Kerugian negara yang diakibatkan oleh tindak pidana korupsi sudah masuk dalam kategori membahayakan. Korupsi di Indonesia merupakan persoalan bangsa yang bersifat recurrent dan darurat yang telah dihadapi bangsa Indonesia dari masa ke masa dalam rentang waktu relatif lama, sehingga pengadilan khusus korupsi diharapkan dapat membantu menyelesaikan sejumlah kejahatan korupsi masa lalu agar mengembalikan kekayaan negara yang hilang. ${ }^{1}$

Ada saja metode korupsi baru yang muncul dan memberikan dampak negatif kepada masyarakat. Proyek-proyek pemerintah yang bertujuan demi kesejahteraan seluruh rakyat Indonesia acap kali diselewengkan penggunaan dananya demi kepentingan golongan tertentu. Jalan-jalan akses vital tak kunjung rampung pengerjaannya, perlindungan kesehatan tidak menyentuh mereka yang membutuhkan, pembangunan sarana prasarana fisik yang tak sesuai dengan spesifikasinya, sampai pengebirian dana-dana pendidikan untuk anak-anak calon penerus bangsa di masa depan. Hal-hal tersebut adalah beberapa contoh ketidakpedulian koruptor terhadap kepentingan masyarakat umum.

Bertambah besar volume pembangunan bertambah besar pula kemungkinan kebocoran. ${ }^{2}$ Ditambah dengan gaji pegawai negeri yang memang sangat minim di negara-negara berkembang seperti Indonesia, pegawai negeri terdorong untuk melakukan perbuatan-perbuatan yang kadang-kadang menggunakan kekuasaannya untuk menambah penghasilannya.

Beragam terobosan hukum dan penguatan fungsi lembaga telah diupayakan aparat penegak hukum demi terberantasnya korupsi dari Indonesia. Pergantian Kepala Negara atau pucuk pimpinan instansi penegak hukum biasanya dibarengi dengan pergantian metode dan pendekatan untuk pemberantasan korupsi, mulai dari merumuskan regulasi oleh masing-masing institusi penegakan hukum, menyepakati suatu nota kesepahaman antar lembaga, hingga pembekalan aparat penegak hukum dengan kemampuan tekhnis dan akademis agar tak kalah cerdik dari koruptor.

\footnotetext{
1 Michael Barama, "Uang Pengganti Sebagai Pidana Tambahan Dalam Perkara Korupsi", artikel diakses pada tanggal $11 \quad$ Februari 2016 pada: http://repo.unsrat.ac.id/75/1/UANG PENGGANTI SEBAGAI PIDANA TAMBAHAN DALAM P ERKARA_KORUPSI.pdf, h.15.

2 Andi Hamzah, Pemberantasan Korupsi Melalui Hukum Pidana Nasional dan Internasional, (Jakarta: PT. Raja Grafindo Persada, 2014, ), h. 229.
}

34 - Jurnal Cita Hukum. Vol. 4 No. 1 Juni 2016. P-ISSN: 2356-1440. E-ISSN: 2502-230X 
Menyikapi suatu tindak pidana dapat dilakukan dengan cara preventif dan represif. Bentuk represif tersebut adalah dengan pengenaan pidana terhadap para koruptor sesuai dengan tindak pidana yang telah dilakukan. Andi Hamzah, dalam bukunya "Asas-asas Hukum Pidana" menulis bahwa tujuan pidana ${ }^{3}$ dalam literatur bahasa inggris yaitu $3 \mathrm{R}$ dan 1 D: 1 ). Reformation, yang berarti memperbaiki atau merehabilitasi penjahat menjadi orang baik berguna bagi masyarakat; 2). Restraint maksudnya mengasingkan pelanggar dari masyarakat; 3). Retribution, yang berarti pembalasan terhadap pelanggar karena telah melakukan kejahatan; dan, 4). Deterrence, berarti menjera atau mencegah sehingga baik terdakwa sebagai individual maupun orang lain yang potensial menjadi penjahat akan jera atau takut melakukan kejahatan, melihat pidana yang dijatuhkan kepada terdakwa.

Sistem hukum Indonesia dalam hukum-hukum positifnya telah mengatur pidana yang dapat dikenakan terhadap koruptor. Sebagai pidana pokok dapat dijerat antara lain dengan pidana penjara dengan waktu tertentu, pidana seumur hidup sampai pidana mati sebagaimana jenis pidana pokok dalam KUHP dan redaksi pasal-pasal dalam Undang-Undang Nomor 31 Tahun 1999 sebagaimana telah diubah dan ditambah dengan Undang-Undang Nomor 20 Tahun 2001 (selanjutnya disebut Undang-Undang PTPK). Selain pidana pokok juga diatur mengenai pidana tambahan yang meliputi pencabutan hakhak tertentu, perampasan barang bukti dan pengumuman putusan hakim. Pidana tambahan dalam KUHP diperluas pengertiannya menurut pasal 18 Undang-Undang PTPK meliputi perampasan benda bergerak dan atau tidak bergerak, pembayaran uang pengganti, penutupan usaha, dan pencabutan seluruh atau sebagian hak-hak tertentu.

Salah satu jenis pidana tambahan yang merupakan ciri khas perkara korupsi adalah pidana pembayaran uang pengganti. Pengenaan pidana tambahan uang pengganti sendiri diatur dalam pasal 18 ayat (1) huruf $b$, pasal 18 ayat (2) dan pasal 18 ayat (3) Undang-Undang PTPK. Pidana pembayaran uang pengganti ${ }^{4}$ merupakan konsekuensi dari akibat tindak pidana korupsi yang "dapat merugikan keuangan negara atau perekonomian negara", sehingga untuk mengembalikan kerugian tersebut diperlukan sarana yuridis yakni dalam bentuk pembayaran uang pengganti. Konsep pembayaran uang

${ }^{3}$ Didik Endro Purwoleksono, Hukum Pidana, (Surabaya: Airlangga University Press,2014), h. 91.

${ }^{4}$ Alamando Jefri Teguh Manurung, dkk, artikel diakses 11 Februari 2016 dari: "Efektivitas Pelaksanaan Pidana Pembayaran Uang Pengganti Oleh Kejaksaan Dalam Tindak Pidana Korupsi" dalam http://hukum.ub.ac.id/wp-content/uploads/2013/09/371 JURNAL-ALMANDO.pdf. 


\section{B.G.M. Widipradnyana Arjaya}

pengganti adalah untuk membalas agar pelaku korupsi tidak menikmati hasil kejahatannya dan negara dapat memperoleh pengembalian uang yang diderita.

Besaran uang pengganti adalah sebanyak-banyaknya sama dengan harta yang diperoleh dari tindak pidana korupsi, maka untuk dapat menetapkan besaran uang pengganti yang dituntut terlebih dahulu haruslah mengetahui perolehan harta dari tindak pidana korupsi yang berada dalam penguasaan pelaku korupsi. Penelusuran harta hasil tindak pidana di tangan tersangka yang kemudian akan dikonversikan sebagai besaran uang pengganti adalah dengan mengikuti prinsip follow the money yang kerap digaunggaungkan dalam penanganan tindak pidana korupsi serta pencucian uang. Namun sebelum melaksanakan prinsip follow the money terlebih dahulu harus diketahui aliran dana siapa saja yang menjadi titik awal guna memonitor aliran dana. Untuk itu idealnya penelusuran aset sebaiknya dilaksanakan di tahap penyidikan setelah penyidik menetapkan tersangka dalam perkara korupsi terkait.

Melakukan penelusuran aset harta hasil korupsi juga dimaksud untuk meminimalisir kemungkinan sebagai berikut: a). Koruptor dalam mengelola hasil korupsi tidak meletakkannya dalam penguasaan dirinya sendiri. Harta hasil korupsi tersebut berada pada anggota keluarga atau pihak ketiga yang dipercaya olehnya; dan, b). setelah mengetahui dirinya ditetapkan sebagai tersangka kemudian menjual atau memindahtangankan harta perolehan korupsinya kepada pihak lain untuk menghindari dilakukannya penyitaan oleh penyidik atau penuntut umum di kemudian hari.

Kecermatan aparat penegak hukum untuk menghitung berapa besar harta hasil tindak pidana yang dinikmati oleh pelaku sejak tahap penyidikan juga memegang peran penting saat melaksanakan eksekusi putusan pengadilan di kemudian hari. Dalam hal harta hasil korupsi yang dinikmati jumlahnya sudah berkurang karena satu dan lain hal, sehingga tak mencukupi untuk membayar uang pengganti, maka jaksa eksekutor dapat merampas harta milik terpidana. Kerap ditemukan situasi di mana terpidana sebenarnya mampu untuk melunasi uang pengganti, namun enggan untuk membayar apabila menggunakan uang yang diperolehnya di luar hasil korupsi, sehingga subsidiair pidana pengganti diberlakukan oleh jaksa eksekutor. Dengan dilakukannya penelusuran aset maka terpidana tidak dapat mengelak dengan mengatakan tidak memiliki harta yang cukup untuk membayar uang pengganti karena jaksa telah memiliki data rincian harta dari terpidana baik yang diperoleh sebagai hasil korupsi maupun harta yang halal. 


\section{Uang Pengganti Sebagai Pidana Tambahan Dalam Perkara Korupsi}

Secara umum jenis pemidanaan dalam hukum pidana Indonesia dapat dilihat pada pasal 10 KUHP yang terbagi atas pidana pokok dan pidana tambahan. Pidana pokok meliputi pidana mati, pidana penjara, pidana kurungan, pidana denda, dan pidana tutupan. Pidana tambahan meliputi pencabutan hak-hak tertentu, perampasan barang bukti dan pengumuman putusan hakim.

Dalam tindak pidana korupsi pidana tambahan sebagaimana Pasal 10 KUHP diperluas pengertiannya dalam redaksi pasal 18 ayat (1) UndangUndang PTPK, yang menyatakan bahwa: "Selain pidana tambahan dimaksud dalam Kitab Undang-undang Hukum Pidana sebagai pidana tambahan adalah: a). Perampasan barang bergerak yang berwujud atau yang tidak berwujud barang tidak bergerak yang digunakan untuk yang diperoleh dari tindak pidana korupsi, termasuk perusahaan milik terpidana di mana tindak pidana korupsi dilakukan, begitu pun harga dari barang yang menggantikan barang tersebut; b). Pembayaran uang pengganti yang jumlahnya sebanyak-banyaknya dengan harta benda yang diperoleh dari tindak pidana korupsi; c). Penutupan usaha atau sebagian perusahaan untuk waktu paling lama 1 (satu) tahun; dan d). Pencabutan seluruh atau sebagian hak-hak tertentu atau penghapusan atau sebagian keuntungan tertentu, yang telah atau dapat diberikan oleh Pemerintah kepada terpidana".

Ubi non est principalis, non potest esse accessories: di mana tidak ada hal yang pokok, maka tidak mungkin ada hal tambahan. Demikian postulat yang melandasi hal-hal yang bersifat pokok dan hal-hal yang bersifat tambahan. Oleh karena itu, pidana tambahan tidak boleh dijatuhkan tanpa pidana pokok. Namun tidak sebaliknya, pidana pokok boleh dijatuhkan tanpa pidana tambahan. Lebih lanjut, hakim boleh menjatuhkan hanya satu pidana pokok dengan lebih dari satu pidana tambahan. ${ }^{5}$

Pidana tambahan memiliki beberapa perbedaan dengan pidana pokok ${ }^{6}$, yaitu: 1). Penjatuhan salah satu jenis pidana pokok adalah suatu keharusan atau imperatif. Sedangkan penjatuhan pidana tambahan bersifat fakultatif. Apabila dalam suatu persidangan terbukti bahwa terdakwa bersalah secara sah dan meyakinkan, maka hakim harus menjatuhkan salah satu pidana pokok sesuai

${ }^{5}$ Eddy O.S. Hiariej, Prinsip-Prinsip Hukum Pidana, (Yogyakarta: Cahaya Atma Pustaka, 2014), h. 402.

6 Michael Barama, "Uang Pengganti Sebagai Pidana Tambahan Dalam Perkara Korupsi", artikel diakses pada 11 Februari 2016 dari: http://repo.unsrat.ac.id/75/1/UANG PENGGANTI SEBAGAI PIDANA TAMBAHAN DALAM P ERKARA_KORUPSI.pdf, h. 18. 


\section{B.G.M. Widipradnyana Arjaya}

jenis dan batas maksimum dari rumusan tindak pidana yang dilanggar tersebut. Sifat imperatif dapat dilihat pada rumusan tindak pidana, di mana terdapat dua kemungkinan yaitu diancamkan salah satu pidana pokok sehingga hakim mau tidak mau harus menjatuhkan pidana sesuai rumusan tersebut atau dapat juga tindak pidana yang diancam oleh dua atau lebih tindak pidana pokok, sehingga hakim dapat memilih salah satu saja. Misalnya pada pasal 2 ayat (2) UNDANG-UNDANG PTPK memilih jenis pidana seumur hidup atau selama waktu tertentu antara empat tahun hingga dua puluh tahun; 2). Penjatuhan jenis pidana pokok harus bersamaan dengan pidana tambahan (berdiri sendiri), sedangkan penjatuhan pidana tambahan harus bersamaan dengan pidana pokok; 3). Jenis pidana pokok yang dijatuhkan, bila telah mempunyai kekuatan hukum tetap diperlukan pelaksanaan (executie), sedangkan pidana tambahan tidak. Pada pidana pokok diperlukan eksekusi terhadap pencapaian pidana tersebut kecuali pidana pokok dengan bersyarat (pasal 14a) dan syarat yang ditentukan itu tidak dapat dilanggar. Pada pidana tambahan misalnya pidana pengumuman putusan hakim; dan, 4). Pidana pokok tidak dapat dijatuhkan kumulatif, sedangkan pidana tambahan dapat. Akan tetapi dapat disimpangi pada beberapa Undang-Undang termasuk Undang-Undang PTPK.

Jenis pidana tambahan yang kerap muncul dalam perkara korupsi adalah pembayaran uang pengganti. Pidana tambahan uang pengganti terhadap terdakwa biasanya muncul dalam suatu perkara yang terdapat kerugian negara di dalamnya. Untuk tahun 2015 saja menurut Pemantauan ICW $^{7}$ terhadap 524 perkara korupsi dengan 564 terdakwa yang telah diputus oleh pengadilan, baik di tingkat pertama, banding, kasasi, maupun peninjauan kembali (PK), jumlah uang pengganti yang diputus oleh Majelis hakim dari seluruh tahapan peradilan adalah sebesar Rp.1.542.360.967.116.78 atau Rp.1,5 Triliun. Basrief Arief berpendapat "pengembalian kerugian negara dari tindak pidana korupsi melalui uang pengganti merupakan salah satu upaya penting dalam pemberantasan tindak pidana korupsi. ${ }^{8}$ Pengembalian tersebut tidaklah mudah karena tindak pidana korupsi merupakan extra ordinary crimes yang

2016

${ }^{7}$ Indonesia Corruption Watch, Tren Vonis Korupsi 2015, artikel diakses pada 11 Februari http://www.antikorupsi.org/sites/antikorupsi.org/files/files/Siaran\%20Pers/Tren\%20Vonis\%20Koru psi\%202015.pdf.

8 Pusat Litbang Kejaksaan Agung R.I, "Studi tentang Langkah Hukum Yang Harus Ditempuh Dalam upaya Penyelesaian Tunggakan Pembayaran Uang Pengganti", artikel diakses $\begin{array}{llll}\text { pada } & 10 & \text { Februari } & 2016 \\ \end{array}$ https://www.kejaksaan.go.id/unit_kejaksaan.php?idu=28\&idsu=35\&id=53. 
pelakukanya berasal dari kalangan intelektual dan mempunyai kedudukan penting."

Selain dalam pasal 18 ayat (1) huruf b dan pasal 18 ayat (2) dan ayat (3) Undang-Undang PTPK, aturan mengenai uang pengganti dapat ditemukan juga dalam Peraturan Mahkamah Agung Republik Indonesia Nomor 5 Tahun 2014 tentang Pidana Tambahan Uang Pengganti dalam Tindak Pidana Korupsi (selanjutnya disebut PERMA No. 5 Tahun 2014). PERMA No. 5 Tahun 2014 ini sebagaimana dalam konsideran menimbang merupakan pedoman dari Mahkamah Agung dalam penjatuhan pidana tambahan pembayaran uang pengganti dalam tindak pidana korupsi.

Pembayaran uang pengganti sendiri dapat dikenakan baik terhadap pelaku yang merupakan subyek hukum perorangan dan atau korporasi, dengan ketentuan bahwa korporasi yang dikenakan pidana tambahan uang pengganti terhadap korporasi tersebut tidak dapat dijatuhi penjara pengganti atas uang pengganti. Adapun pidana tambahan uang pengganti hanya dapat dikenakan kepada terdakwa dalam perkara bersangkutan sebagaimana rumusan Pasal 6 PERMA No. 5 Tahun 2014, dan tidak dapat dikenakan kepada pihak lain diluar terdakwa dalam perkara bersangkutan. Dalam hal tindak pidana korupsi dilakukan secara bersama-sama, maka hakim dapat menjatuhkan besaran uang pengganti didasarkan harta benda yang diperoleh masing-masing terdakwa, mengingat dalam pasal 4 PERMA No. 5 Tahun 2014 menyatakan bahwa uang pengganti tidak dapat dijatuhkan secara tanggung renteng. Akan tetapi dalam hal harta benda perolehan korupsi masing-masing terdakwa tidak diketahui secara pasti jumlahnya, uang pengganti dapat dijatuhkan secara proporsional dan objektif sesuai dengan peran masingmasing terdakwa dalam tindak pidana korupsi yang dilakukannya.

Penuntut umum dalam menyusun tuntutan tidak diperkenankan untuk menuntut uang pengganti selain kepada terdakwa dalam perkara bersangkutan'. Tuntutan yang demikian selain tidak memiliki dasar hukum, pada prinsipnya juga melanggar prinsip-prinsip peradilan yang adil (fair trial), oleh karena pihak ketiga tersebut dikenakan tuntutan tanpa pernah diberikan kesempatan untuk melakukan pembelaan diri layaknya terdakwa dalam persidangan yang terbuka untuk umum. Selain itu apabila pengadilan mengabulkan tuntutan JPU yang demikian, maka akan timbul permasalahan hukum dalam eksekusinya. Untuk itu apabila pengadilan mendapatkan perkara di mana dalam surat tuntutannya JPU memasukan tuntutan agar terdapat pihak ketiga, baik saksi maupun terdakwa dalam perkara lain yang

9 Lihat Penjelasan pasal 6 PERMA Nomor 5 tahun 2014. 


\section{B.G.M. Widipradnyana Arjaya}

dijatuhkan pidana tambahan pembayaran uang pengganti, pengadilan menolak tuntutan tersebut dan menyarankan agar JPU mendakwa pihak ketiga terlebih dahulu dalam perkara sendiri. Menjatuhkan pidana tambahan uang pengganti kepada pihak lain selain terdakwa, merupakan suatu pelanggaran terhadap asas presumption of innocence dan fair trial. ${ }^{10}$ Oleh karenanya, hakim tidak dibenarkan untuk menjatuhkan pidana tambahan pembayaran uang pengganti selain kepada terdakwa.

Besaran pembayaran uang pengganti dalam tindak pidana korupsi, adalah sebanyak-banyaknya sama dengan harta benda yang diperoleh dari tindak pidana korupsi dan bukan semata-mata sejumlah kerugian negara yang diakibatkan sebagaimana redaksi Pasal 1 PERMA No. 5 Tahun 2014. Besaran uang pengganti tak harus sama dengan besar kerugian negara karena dalam suatu kasus sangat mungkin bahwa apa yang dinikmati dari pelaku korupsi tak hanya sebatas kerugian negara yang ditimbulkan dari perbuatannya,

Penjatuhan pembayaran uang pengganti ${ }^{11}$ terhadap tindak pidana korupsi selain yang terkait dengan kerugian keuangan negara dapat dijatuhkan jika terdakwa atas perbuatannya memperoleh hasil korupsi sementara itu tidak semua hasil korupsi tersebut dapat dikenakan perampasan berdasarkan pasal 18 ayat (1) huruf a UNDANG-UNDANG PTPK. sebagai contoh dalam perkara penyuapan, harta yang diterima penerima suap pada dasarnya adalah hasil korupsi. Harta tersebut pada prinsipnya haruslah dirampas menjadi milik negara. Namun sangat mungkin harta tersebut sudah tidak berada di tangan terdakwa, baik seluruhnya maupun sebagian sehingga tidak dapat dikenakan penyitaan pada saat penyidikan dan perampasan. Dalam kasus-kasus seperti itu, untuk menghindari terdakwa menikmati hasil korupsi tersebut di kemudian hari, maka atas selisih harta hasil korupsi (uang suap) yang belum dikenakan perampasan dapat dikenakan uang pengganti.

Dalam menentukan tuntutan besaran uang pengganti yang harus dibayarkan JPU harus memperhitungkan hasil korupsi yang telah disita terlebih dahulu oleh penyidik dalam menentukan jumlah uang pengganti yang harus dibayarkan. ${ }^{12} \mathrm{Hal}$ ini dilakukan karena apabila terhadap barang yang telah disita terbukti merupakan hasil tidana maka akan dilakukan tindakan perampasan, pidana penjatuhan pidana tambahan perampasan barang pada prakteknya sering menimbulkan persinggungan. ${ }^{13}$ Bahkan dalam beberapa kasus Majelis hakim melakukan double counting dalam menjatuhkan besaran

\footnotetext{
${ }^{10}$ Lihat Penjelasan pasal 3 PERMA Nomor 5 tahun 2014.

${ }^{11}$ Lihat Penjelasan pasal 3 PERMA Nomor 5 tahun 2014.

${ }^{12}$ Lihat Pasal 2 PERMA Nomor 5 tahun 2014.

${ }^{13}$ Lihat Penjelasan Umum PERMA Nomor 5 tahun 2014.
}

40 - Jurnal Cita Hukum. Vol. 4 No. 1 Juni 2016. P-ISSN: 2356-1440. E-ISSN: 2502-230X 
pidana tambahan uang pengganti dan perampasan aset. Oleh karenanya, penentuan besaran uang pengganti yang akan dijatuhkan harus dikurangi terlebih dahulu dengan hasil korupsi yang telah dikenakan perampasan.

\section{Menelusuri Aset Tersangka Untuk Menentukan Besar Uang Pengganti}

Undang-Undang PTPK dalam pasal 18 ayat (1) huruf b menyatakan bahwa jumlah pengenaan pidana tambahan pembayaran uang pengganti adalah sebanyak-banyaknya sama dengan harta benda yang diperoleh dari tindak pidana korupsi. Besaran pembayaran uang pengganti ini dipertegas lagi dalam pasal 1 PERMA No 5 tahun 2014 yang menambahkan bahwa jumlah pembayaran uang pengganti dalam tindak pidana korupsi adalah sebanyakbanyaknya sama dengan harta benda yang diperoleh dari tindak pidana korupsi dan bukan semata-mata sejumlah kerugian negara yang diakibatkan. Maka apabila Penuntut Umum ingin menjerat terdakwa dengan pembayaran uang pengganti, penelusuran aset penting dilakukan meski sudah dilakukan audit kerugian negara. Penelusuran aset adalah cara untuk mengetahui berapa besaran riil keuntungan yang dinikmati pelaku dari perbuatannya, dan juga untuk mencegah aset-aset hasil korupsi tidak dipindahtangankan kepada pihak ketiga oleh terdakwa.

Penelusuran aset idealnya dimulai pada tahap penyidikan, karena tahap penyidikan baik penyidik Polri, Kejaksaan maupun KPK sudah menetapkan pihak yang dinyatakan sebagai tersangka, nama-nama yang patut diduga menguasai harta hasil korupsi yaitu tersangka dan orang-orang dekatnya yang terindikasi memiliki andil dalam perkara dimaksud sudah dapat diperkirakan dan pengumpulan alat bukti bisa lebih terfokus kepada nama-nama tersebut. Sebagaimana redaksi pasal 28 UNDANG-UNDANG PTPK “Untuk kepentingan penyidikan, tersangka wajib memberikan keterangan tentang seluruh harta bendanya dan harta benda istri atau suami, anak dan harta benda setiap korporasi yang diketahui dan atau yang diduga mempunyai hubungan dengan tindak pidana korupsi yang dilakukan tersangka."

Pada tahap penyidikan, penelusuran aset terhadap pelaku tindak pidana melekat dengan kewajiban dari penyidik untuk mengumpulkan alat bukti. Namun apabila penyidik berkeinginan untuk mengumpulkan alat bukti lain guna memenuhi unsur-unsur tindak pidana yang dilakukan oleh tersangka, maka penyidik dapat meminta bantuan pihak yang memiliki spesialisasi dalam hal penelusuran aset. 


\section{B.G.M. Widipradnyana Arjaya}

Salah satu lembaga yang diberi kewenangan oleh peraturan perundang-undangan Indonesia untuk melakukan penelusuran aset adalah Pusat Pemulihan Aset (PPA) yang termasuk dalam struktur kelembagaan Kejaksaan Agung Republik Indonesia. Peraturan perundang-undangan yang memberikan kewenangan tersebut kepada PPA adalah Peraturan Jaksa Agung Republik Indonesia Nomor: PER-006/A/JA/3/2014 tanggal 20 Maret 2014 tentang Pemulihan Aset (selanjutnya disebut PERJA Pemulihan Aset), di mana dalam pasal 3 ayat (2) menyatakan bahwa Pemulihan aset sebagaimana dimaksud dalam ayat (1) dilakukan oleh Pusat Pemulihan Aset yang dibentuk berdasarkan ketentuan peraturan perundang-undangan.

Penelusuran aset sendiri merupakan salah satu tahapan dari rangkaian pemulihan aset yang meliputi ${ }^{14}$ proses penelusuran, pengamanan, pemeliharaan, perampasan, pengembalian, dan pelepasan aset tindak pidana atau barang milik negara yang dikuasai pihak lain kepada korban atau yang berhak pada setiap tahap penegakan hukum. Untuk memastikan agar kelima tahapan pemulihan aset sebagaimana dimaksud, maka perlu dilakukan dengan system pemulihan aset terpadu ${ }^{15}$ (Integrated Asset Recovery System/IARS) yang terpusat pada Pusat Pemulihan Aset sebagai otoritas kejaksaan di bidang pemulihan aset, yang terhubung dan didukung oleh semua satuan kerja kejaksaan se-Indonesia dalam suatu database pemulihan aset nasional.

Penelusuran aset menurut PERJA Pemulihan Aset adalah serangkaian tindakan mencari, meminta, memperoleh dan menganalisis informasi untuk mengetahui atau mengungkap asal usul dan keberadaan aset. Aset sendiri menurut pasal 1 angka 1 PERJA Pemulihan Aset memiliki definisi semua benda, baik materiil maupun immaterial, bergerak atau tidak bergerak, berwujud atau tidak berwujud, dan dokumen atau instrumen hukum yang memiliki nilai ekonomis. Dalam konteks tindak pidana di mana dalam tulisan ini adalah tindak pidana korupsi, aset yang dimaksud adalah sebagaimana rumusan Pasal 1 angka 4 PERJA Pemulihan Aset, yaitu aset tindak pidana yang meliputi aset yang diperoleh dari tindak pidana atau diduga berasal dari tindak pidana, aset yang digunakan untuk melakukan tindak pidana, serta aset terkait tindak pidana.

Kegiatan penelusuran aset dapat dilakukan terhadap aset-aset sebagai berikut: a). Aset yang diperoleh secara langsung atau tidak langsung dari tindak pidana termasuk yang telah dihibahkan atau dikonversikan menjadi

${ }^{14}$ Lihat Pasal 1 angka 10 PERJA Pemulihan Aset.

15 Lihat Latar belakang Peraturan Jaksa Agung Republik Indonesia Nomor: PER027/A/JA/10/2014 tentang Pedoman Pemulihan Aset (selanjutnya disebut PERJA Pedoman Pemulihan Aset).

42 - Jurnal Cita Hukum. Vol. 4 No. 1 Juni 2016. P-ISSN: 2356-1440. E-ISSN: 2502-230X 
harta kekayaan pribadi, orang lain, atau korporasi baik berupa modal, pendapatan maupun keuntungan ekonomi lainnya yang diperoleh dari kekayaan tersebut atau aset yang diduga kuat digunakan atau telah digunakan untuk melakukan tindak pidana; b). Barang temuan; c). Aset negara yang dikuasai pihak yang tidak berhak; dan, d). Aset-aset lain sesuai ketentuan peraturan perundang-undangan termasuk yang pada hakekatnya merupakan kompensasi kepada korban dan/atau kepada yang berhak.

Sebelum melaksanakan penelusuran aset, praktisi pemulihan aset terlebih dahulu melakukan profiling dan pemetaan aset. Profiling adalah tindakan untuk mendapatkan identitas pelaku, keluarga dan pihak terkait serta riwayat pekerjaan dan gaya hidupnya, dan pemetaan aset yaitu tindakan untuk mengklasifikasikan aset atau barang. Setelah identitas pelaku, keluarga dan pihak terkait dengan penguasaan harta diduga hasil korupsi diperoleh melalui tahap profiling maka praktisi pemulihan aset dapat mengumpulkan informasi mengenai aset dari pihak-pihak terkait kepada instansi atau lembaga antara lain: ${ }^{16}$ a). Kementerian Kehutanan untuk HPH; b). Kementerian Dalam Negeri untuk data kependudukan; c). Kementerian Pendidikan dan Kebudayaan untuk latar belakang pendidikan; d). Kementerian Energi dan Sumber Daya Mineral untuk pertambangan; e). Badan Pertanahan Nasional untuk tanah/ bangunan yang sudah bersertifikat; f). Kepolisian Negara Republik Indonesia, terkait Bukti Kepemilikan Kendaraan Bermotor (BPKP), Surat Tanda Kendaraan Bermotor (STNK), Surat Ijin Mengemudi, Ijin Gangguan, dan lainnya; g). Pusat Pelaporan dan Analisis Transaksi Keuangan (PPATK) atau Lembaga Keuangan Bank dan Non Bank untuk informasi transaksi keuangan; h). Direktorat Jenderal Perhubungan Udara untuk informasi kepemilikan dan pendaftaran pesawat udara; i). Direktorat Jenderal Perhubungan Laut untuk informasi kepemilikan dan pendaftaran kapal laut; j). Direktorat Jenderal Administrasi Hukum Umum terkait data/akta perusahaan; k). Direktorat Jenderal Imigrasi, terkait paspor; 1). Direktorat Jenderal Pajak, untuk informasi kekayaan Wajib Pajak, Surat Pemberitahuan Pajak Terutang (SPPT); m). Pemerintah Daerah Kabupaten untuk informasi Wajib Pajak Bumi dan Bangunan Khususnya menyangkut SPPT dan Nilai Jual Obyek Pajak (NJOP) Bumi dan Bangunan; n). Sistem Administrasi Manunggal Satu Atap (SAMSAT)/Dinas Pendapatan Daerah (DISPENDA) untuk pajak kendaraan bermotor; o). Kantor Kelurahan/Desa untuk informasi tanah/bangunan yang belum bersertifikat; dan p). Kementerian/lembaga terkait lainnya.

${ }^{16}$ Lihat PERJA Pemulihan Aset, Bab II, Huruf B, Nomor 5. 


\section{B.G.M. Widipradnyana Arjaya}

Sedangkan untuk aset yang berada di luar yurisdiksi Indonesia, dapat dilakukan oleh praktisi pemulihan aset berdasarkan surat perintah Kepala Pusat Pemulihan Aset, dengan menggunakan jalur formal maupun informal atau melalui bantuan timbal balik (MLA) dalam masalah pidana sebagaimana diatur dalam Undang-Undang Republik Indonesia Nomor 1 Tahun 2006 mengingat Pemerintah telah meratifikasi United Nations Convention Against Corruption 2003 yang dituangkan dalam Undang-Undang Republik Indonesia Nomor 7 Tahun 2006.

Dari informasi yang diperoleh maka praktisi pemulihan aset dapat memetakan mana aset yang berasal dari tindak pidana dan mana aset yang bukan berasal dari tindak pidana. Namun perlu diingat bahwa uang pengganti hanya dapat dijatuhkan terhadap terdakwa dalam perkara yang bersangkutan. Terhadap pihak ketiga yang secara sadar menerima penempatan harta yang diketahuinya merupakan hasil korupsi, maka terhadapnya dapat dijerat dengan tindak pidana pencucian uang sebagaimana pasal 5 ayat (1) UndangUndang Republik Indonesia Nomor 8 Tahun 2010 tentang Pencegahan dan Pemberantasan Tindak Pidana Pencucian Uang (selanjutnya disebut UndangUndang TPPU), pun terhadap tersangka yang menempatkan uang tersebut kepadanya dapat dikenakan ancaman pidana yang terdapat dalam pasal 3 Undang-Undang TPPU karena rumusan pasal ini saling berkaitan. Namun terhadap pihak ketiga yang menguasai harta hasil korupsi dari tersangka tanpa mengetahui bahwa harta tersebut merupakan harta hasil korupsi dan terhadapnya tidak dilakukan penyidikan atau penuntutan dalam perkara lain, baik tindak pidana korupsi maupun tindak pidana lain seperti tindak pidana pencucian uang, pihak ketiga tersebut tidak dapat dituntut untuk membayar uang pengganti dan kewajiban pembayaran uang pengganti berada pada terdakwa perkara bersangkutan sebagaimana pasal 5 PERMA No. 5 Tahun 2014.

Setelah berhasil memetakan aset yang berasal dari tindak pidana serta kewajiban tersangka untuk menanggung uang pengganti di kemudian hari maka dilakukan pengamanan ${ }^{17}$ terhadap aset tersebut dengan tujuan untuk menjaga keutuhan, kualitas dan nilai ekonomis. Pengamanan aset sendiri dapat dilakukan dengan cara administratif meliputi pemblokiran dan/atau pembekuan, pengamanan secara fisik; dan pengamanan secara hukum meliputi tindakan penyitaan. Penyidik dapat memilih salah satu bentuk pengamanan atau mengkombinasikan masing-masing jenis pengamanan. Contohnya untuk benda tidak bergerak seperti tanah, bangunan dan rekening tabungan dapat

${ }^{17}$ Lihat Pasal 18 ayat (1) PERJA Pemulihan Aset.

44 - Jurnal Cita Hukum. Vol. 4 No. 1 Juni 2016. P-ISSN: 2356-1440. E-ISSN: 2502-230X 
dilakukan pemblokiran dan untuk benda bergerak seperti kendaraan serta perhiasan dapat dilakukan penyitaan. Pengamanan baik secara administratif, fisik maupun secara hukum meski prosedurnya berbeda memiliki tujuan yang sama untuk mencegah dialihkan atau dipindahtangankan asset, baik dalam tahap penyidikan, penuntutan atau persidangan, selain tujuan yang telah dijelaskan sebelumnya untuk menjaga keutuhan, kualitas dan nilai ekonomis dari aset tersebut.

\section{Hasil Penelusuran Aset Sebagai Alat Bukti di Persidangan}

Hasil dari penelusuran aset yang menyatakan bahwa adanya hasil tindak pidana dalam harta tersangka tak serta merta menyatakan seseorang telah melakukan tindak pidana. Sesuai adagium "innocent until proven guilty" jaksa selaku penuntut umum dalam persidangan memiliki kewajiban untuk membuktikan perbuatan melawan hukum yang dilakukan terdakwa dalam memperoleh harta. Terlebih keputusan apakah harta tersebut merupakan hasil tindak pidana atau tidak tetap berdasarkan keyakinan hakim yang memeriksa dan memutus perkara.

Dalam konteks hukum pidana, pembuktian ${ }^{18}$ merupakan inti persidangan perkara pidana karena yang dicari dalam hukum pidana adalah kebenaran materiil. Kendati pun demikian, pembuktian dalam perkara pidana sudah dimulai sejak tahap penyelidikan untuk mencari dan menemukan peristiwa yang diduga sebagai tindak pidana guna dapat atau tidaknya dilakukan penyidikan. Pada tahap ini sudah terjadi pembuktian, dengan tindak penyidik mencari barang bukti, maksudnya guna membuat terang suatu tindak pidana serta menentukan atau menemukan tersangkanya.

Hasil dari penelusuran aset yang dilakukan di tahap penyidikan bisa menjadi salah satu bentuk alat bukti di persidangan, yaitu alat bukti surat. Sebagaimana disebutkan dalam pedoman pemulihan aset bahwa yang dituangkan dalam suatu bentuk nota dinas atau laporan hasil kegiatan dari pihak yang melakukan pelacakan aset.

Jenis surat yang dapat diterima sebagai alat bukti dalam perkara pidana dicantumkan dalam pasal; 187 KUHAP. Surat tersebut dibuat atas sumpah jabatan atau dikuatkan dengan sumpah. Jenis surat yang dimaksud adalah $^{19}$ : 1). Pertama, berita acara dan surat lain dalam bentuk resmi yang dibuat oleh pejabat umum yang berwenang atau dibuat di hadapannya, yang

\footnotetext{
${ }^{18}$ Eddy O.S. Hiariej, Teori \& Hukum Pembuktian, (Jakarta: Penerbit Erlangga, 2012), h. 7

${ }^{19}$ Eddy O.S. Hiariej, Teori \& Hukum Pembuktian, h.107-109.
} 


\section{B.G.M. Widipradnyana Arjaya}

membuat keterangan tentang kejadian atau keadaan yang didengar, dilihat atau dialaminya sendiri, disertai dengan alasan yang jelas dan tegas tentang keterangannya itu; 2). Kedua, surat yang dibuat menurut ketentuan peraturan perundang-undangan atau surat yang dibuat oleh pejabat mengenai hal yang termasuk dalam tata laksana yang menjadi tanggung jawabnya dan diperuntukkan bagi pembuktian sesuatu hal atau sesuatu keadaan; 3). Ketiga, surat keterangan dari seorang ahli yang memuat pendapat berdasarkan keahliannya mengenai sesuatu hal atau suatu keadaan yang diminta secara resmi dari padanya; 4). Keempat, surat lain yang hanya dapat berlaku jika ada hubungannya dengan isi dari alat pembuktian yang lain. Surat jenis ini hanya mengandung nilai pembuktian apabila isi surat tersebut ada hubungannya dengan alat bukti yang lain.

Bukti surat ${ }^{20}$ mempunyai kekuatan pembuktian yang sempurna dan mengikat bagi hakim dengan syarat: a). Bentuk formil maupun materiil sudah sesuai dengan ketentuan yang diatur oleh Undang-Undang; b). Bahwa surat tersebut tidak ada cacat hukum; c). Tidak ada orang lain yang mengajukan bukti yang dapat melemahkan bukti surat tersebut.

Hasil penelusuran aset digunakan sebagai alat bukti surat terlihat urgensinya pada saat persidangan, di mana dalam persidangan terdakwa wajib memberikan keterangan tentang seluruh harta bendanya dan harta benda istri atau suaminya, anak, dan harta benda setiap orang atau korporasi yang diduga mempunyai hubungan dengan perkara yang didakwakan sebagaimana rumusan Pasal 37 A ayat (1) Undang-Undang PTPK. Hasil penelusuran aset dapat digunakan untuk mengkonfrontasi keterangan yang diberikan terdakwa sehingga hakim dapat menilai kualitas keterangan dari terdakwa, mengingat Pasal 37 A ayat (2) Undang-Undang PTPK menyatakan bahwa apabila terdakwa tidak dapat membuktikan tentang kekayaan yang tidak seimbang dengan penghasilannya atau sumber penambahan kekayaannya maka keterangan tersebut digunakan untuk memperkuat alat bukti yang sudah ada bawa terdakwa telah melakukan tindak pidana korupsi.

Meskipun dalam persidangan terdakwa wajib memberikan keterangan tentang seluruh harta bendanya dan harta benda istri atau suaminya, anak, dan harta benda setiap orang atau korporasi yang diduga mempunyai hubungan dengan perkara yang didakwakan sebagaimana rumusan Pasal 37 A ayat (1) Undang-Undang PTPK penuntut umum tetap berkewajiban untuk membuktikan dakwaaannya sebagaimana rumusan Pasal 37 A ayat (3)

${ }^{20}$ Suharto RM, Penuntutan Dalam Praktek Peradilan, (Jakarta: Sinar Grafika, 2006), h. 154, 155.

46 - Jurnal Cita Hukum. Vol. 4 No. 1 Juni 2016. P-ISSN: 2356-1440. E-ISSN: 2502-230X 
Undang-Undang PTPK, hal ini menurut Adami Chazawi ${ }^{21}$ menunjukkan bahwa pembuktian perkara tindak pidana korupsi yang diterapkan atau diikuti oleh Undang-Undang PTPK adalah "pembuktian terbalik yang bersifat terbatas dan berimbang" atau "pembuktian terbalik yang terbatas" kecuali yang diterapkan atau diikuti pembuktian terbalik sebenarnya adalah "pembuktian biasa" yang melulu mengikuti ketentuan-ketentuan yang terdapat dalam KUHAP.

Hasil penelusuran aset sebagai alat bukti surat dan keterangan terdakwa tersebut diharapkan dapat menimbulkan keyakinan majelis hakim yang memeriksa perkara, mengingat dalam hukum pembuktian perkara pidana diikat dengan beberapa ketentuan ${ }^{22}$ yakni: a). Adanya syarat minimal dua pembuktian, ialah satu alat bukti saja tidaklah cukup dalam perkara pidana, melainkan harus minimal dua alat bukti; b). Diperlukan adanya keyakinan hakim. Dari minimal dua alat bukti terbentuklah keyakinan tentang 3 hal (terjadi tindak pidana, terdakwa melakukannya, dan ia dapat dipersalahkan atas perbuatannya itu).

Muara dari kerja keras penyidik mengumpulkan alat bukti dan penuntut umum membuktikan adanya uang pengganti yang harus dibayar terdakwa adalah teryakininya majelis hakim pemeriksa perkara dan mengabulkan tuntutan pidana tambahan uang pengganti. Keyakinan majelis hakim tersebut dituangkan ke dalam putusan pengadilan. Putusan pengadilan menurut pasal 1 angka 11 KUHAP memiliki definisi pernyataan hakim yang diucapkan dalam sidang pengadilan terbuka, yang dapat berupa pemidanaan atau bebas atau lepas dari segala tuntutan hukum dalam hal serta menurut cara yang diatur dalam undang-undang ini.

Ada dua jenis putusann ${ }^{23}$, yaitu: 1). Putusan pemidanaan, apabila yang didakwakan oleh penuntut umum dalam surat dakwaannya telah terbukti secara sah dan meyakinkan; 2). Putusan yang bukan pemidanaan dapat berupa putusan bebas (vrijspraak) dan putusan lepas dari segala tuntutan hukum (onslag van recht vervolging).

Putusan yang diharapkan tentu saja adalah putusan pemidanaan yang menyatakan dakwaan penuntut umum terbukti secara sah dan meyakinkan. Akan tetapi keberadaan putusan ini tak serta merta berkekuatan hukum selama pihak penuntut umum atau terdakwa masih belum puas dan masih ada upaya

${ }^{21}$ Adami Chazawi, Hukum Pembuktian Tindak Pidana Korupsi, (Malang: Banyumedia Publishing, 2013), h. 222.

${ }^{22}$ Adami Chazawi, Hukum Pembuktian Tindak Pidana Korupsi, h. 54-55.

${ }^{23}$ Lilik Mulyadi, Hukum Acara Pidana Indonesia, Suatu Tinjauan Khusus Terhadap: Surat Dakwaan, Eksepsi, dan Putusan Pengadilan, (Bandung: PT Citra Aditya Bakti, 2012) h.125. 


\section{B.G.M. Widipradnyana Arjaya}

hukum yang dapat ditempuh. Suatu putusan baru dapat dieksekusi apabila para pihak telah menerima putusan dan tidak mengajukan upaya hukum terhadapnya.

Setelah suatu putusan pengadilan berkekuatan hukum tetap atau dikenal dengan istilah inkracht van gewijsde, maka sebagaimana pasal 30 ayat (1) huruf b Undang-undang Nomor 16 tahun 2004 tentang Kejaksaan Republik Indonesia dan pasal $270 \mathrm{KUHAP}$, jaksa berkewajiban untuk melaksanakan atau mengeksekusi putusan pengadilan yang telah berkekuatan hukum tetap tersebut. Dengan dilakukannya penelusuran uang pengganti dan pembekuan atau pemblokiran aset maka eksekusi putusan pengadilan berkekuatan hukum tetap yang amarnya memerintahkan terpidana untuk membayar uang pengganti tidak akan menemui kendala dalam hal terpidana yang mengaku tidak memiliki harta untuk membayar uang pengganti dan memilih untuk menjalani penjara pengganti. Mengingat harta hasil korupsi telah disita atau diblokir sejak tingkat penyidikan dalam tindakan pengamanan aset, maka jaksa eksekutor akan lebih mudah untuk melakukan eksekusi berdasarkan putusan berkekuatan hukum tetap. Selain itu apabila ditemukan bahwa karena satu dan lain hal nilai harta hasil korupsi mengalami penyusutan dari saat majelis hakim menetapkan besaran uang pengganti, maka jaksa eksekutor dapat melakukan pelelangan terhadap harta terpidana sebagaimana rumusan pasal 18 ayat (2) PTPK. Terpidana tak dapat berdalih tidak memiliki harta yang cukup dan memilih untuk menjalankan subsidiair penjara pengganti sebagaimana pasal 18 ayat (3) Undang-Undang PTPK karena jaksa eksekutor telah mengetahui besaran harta yang dimiliki dari terpidana dari kegiatan penelusuran aset yang telah dilakukan sebelumnya.

\section{Penutup}

Penelusuran aset hasil korupsi penting untuk dilakukan sejak tahap penyidikan guna mengetahui besaran harta hasil korupsi yang berada dalam penguasaan tersangka, hasil penelusuran aset ini adalah dasar untuk menetapkan besaran uang pengganti yang akan dibebankan di kemudian hari kepada terpidana, sebagaimana Undang-Undang PTPK dalam pasal 18 ayat (1) huruf $\mathrm{b}$ menyatakan bahwa besaran uang pengganti adalah sebanyakbanyaknya sama dengan harta yang dinikmati terdakwa. Dalam hukum acara pidana, hasil penelusuran aset tersebut di persidangan bisa menjadi suatu alat bukti adanya harta hasil korupsi yang berada dalam penguasaan terdakwa yang dapat menguatkan dalil-dalil penuntut umum serta sebagai pertimbangan hakim untuk memutus sesuai dengan tuntutan yang diajukan oleh penuntut umum.

48 - Jurnal Cita Hukum. Vol. 4 No. 1 Juni 2016. P-ISSN: 2356-1440. E-ISSN: 2502-230X 
Apabila setelah dilakukan kegiatan penelusuran aset ditemukan fakta aset tersebut telah dipindahtangankan atau ditempatkan tersangka kepada pihak ketiga, bukan berarti harta tersebut tidak dapat dituntut secara hukum. Banyak opsi yang dapat diambil oleh jaksa, antara lain Jaksa tetap dapat menuntut pidana tambahan uang pengganti kepada terdakwa sepanjang pihak ketiga tidak dituntut pidana, atau menuntut dalam perkara terpisah sebagai suatu pencucian uang, atau sebagai alat bukti untuk menetapkan tersangka baru apabila ditemukan bukti bahwa pihak ketiga tersebut secara aktif turut serta melakukan korupsi yang sama.

\section{Pustaka Acuan}

\section{Buku}

Chazawi, Adami, Hukum Pembuktian Tindak Pidana Korupsi, Malang: Banyumedia Publishing, 2013.

Hamzah, Andi, Pemberantasan Korupsi Melalui Hukum Pidana Nasional dan Internasional, Jakarta: PT. Raja Grafindo Persada, 2014

Hiariej, Eddy O.S., Prinsip-Prinsip Hukum Pidana, Yogyakarta: Cahaya Atma Pustaka, 2014.

Hiariej, Eddy O.S., Teori \& Hukum Pembuktian, Jakarta: Penerbit Erlangga, 2012.

Mulyadi, Lilik, Hukum Acara Pidana Indonesia Suatu Tinjauan Khusus Terhadap: Surat Dakwaan, Eksepsi, dan Putusan Pengadilan, Bandung: PT Citra Aditya Bakti, 2012.

Purwoleksono, Didik Endro, Hukum Pidana, Surabaya: Airlangga University Press, 2014.

RM, Suharto, Penuntutan Dalam Praktek Peradilan, Jakarta: Sinar Grafika, 2006

Wiyono, R., Pembahasan Undang-Undang Pemberantasan Tindak Pidana Korupsi, Jakarta: Sinar Grafika, 2013.

\section{Peraturan Perundang-Undangan}

Undang-Undang Republik Indonesia Nomor 8 Tahun 1981 tentang Hukum Acara Pidana (KUHAP)

Undang-Undang Republik Indonesia Nomor 31 Tahun 1999 sebagaimana telah diubah dan ditambahkan dengan Undang-Undang Nomor 20 Tahun 2001 tentang Pemberantasan Tindak Pidana Korupsi

Undang-Undang Republik Indonesia Nomor 16 Tahun 2004 Tentang Kejaksaan Republik Indonesia 


\section{B.G.M. Widipradnyana Arjaya}

Undang-Undang Republik Indonesia Nomor 07 Tahun 2006 Tentang Pengesahan United Nations Convention Against Corruption,2003 (Konvensi Perserikatan Bangsa-Bangsa Anti Korupsi, 2003)

Undang-Undang Republik Indonesia Nomor 08 Tahun 2010 Tentang Pencegahan dan Pemberantasan Tindak Pidana Pencucian Uang

Peraturan Mahkamah Agung Republik Indonesia Nomor 5 Tahun 2014 tentang Pidana Tambahan Uang Pengganti dalam Tindak Pidana Korupsi

Peraturan Jaksa Agung Republik Indonesia Nomor: PER-013/A/JA/06/2014 tentang Pemulihan Aset

Peraturan Jaksa Agung Republik Indonesia Nomor: PER-027/A/JA/10/2014 tentang Pedoman Pemulihan Aset

\section{Internet}

Alamando Jefri Teguh Manurung, dkk, Efektivitas Pelaksanaan Pidana Pembayaran Uang Pengganti Oleh Kejaksaan Dalam Tindak Pidana Korupsi, dalam http://hukum.ub.ac.id/wpcontent/uploads/2013/09/371 JURNAL-ALMANDO.pdf , diunduh pada 11 Februari 2016

Indonesia Corruption Watch, Tren Vonis Korupsi 2015, dalam http://www.antikorupsi.org/sites/antikorupsi.org/files/files/Siaran\%20P ers/Tren\%20Vonis\%20Korupsi\%202015.pdf , diunduh pada 11 Februari 2016

Michael Barama, Uang Pengganti Sebagai Pidana Tambahan Dalam Perkara Korupsi, dalam http://repo.unsrat.ac.id/75/1/UANG PENGGANTI SEBAGAI PIDAN A TAMBAHAN DALAM PERKARA KORUPSI.pdf, diunduh pada 11 Februari 2016

Pusat Litbang Kejaksaan Agung R.I, Studi tentang Langkah Hukum Yang Harus Ditempuh Dalam upaya Penyelesaian Tunggakan Pembayaran Uang Pengganti, 2008, https://www.kejaksaan.go.id/unit kejaksaan.php?idu=28\&idsu=35\&id= $\underline{53}$, diunduh pada 10 Februari 2016

50 - Jurnal Cita Hukum. Vol. 4 No. 1 Juni 2016. P-ISSN: 2356-1440. E-ISSN: 2502-230X 